\title{
Finding gaps in TB notifications: spatial analysis of geographical patterns of TB notifications, associations with TB program efforts and social determinants of TB risk in Bangladesh, Nepal and Pakistan
}

Margo van Gurp ${ }^{1 *}$ (D), Ente Rood ${ }^{1}$, Razia Fatima ${ }^{2}$, Pushpraj Joshi ${ }^{3}$, Sharat Chandra Verma ${ }^{3}$, Ahmadul Hasan Khan ${ }^{4}$, Lucie Blok' Christina Mergenthaler ${ }^{1}$ and Mirjam Irene Bakker ${ }^{1}$

\begin{abstract}
Background: In order to effectively combat Tuberculosis, resources to diagnose and treat TB should be allocated effectively to the areas and population that need them. Although a wealth of subnational data on TB is routinely collected to support local planning, it is often underutilized. Therefore, this study uses spatial analytical techniques and profiling to understand and identify factors underlying spatial variation in TB case notification rates (CNR) in Bangladesh, Nepal and Pakistan for better TB program planning.

Methods: Spatial analytical techniques and profiling was used to identify subnational patterns of TB CNRs at the district level in Bangladesh $(N=64,2015)$, Nepal $(N=75,2014)$ and Pakistan $(N=142,2015)$. A multivariable linear regression analysis was performed to assess the association between subnational CNR and demographic and health indicators associated with TB burden and indicators of TB programme efforts. To correct for spatial dependencies of the observations, the residuals of the multivariable models were tested for unexplained spatial autocorrelation. Spatial autocorrelation among the residuals was adjusted for by fitting a simultaneous autoregressive model (SAR).

Results: Spatial clustering of TB CNRs was observed in all three countries. In Bangladesh, TB CNR were found significantly associated with testing rate $(0.06 \%, p<0.001)$, test positivity rate $(14.44 \%, p<0.001)$, proportion of bacteriologically confirmed cases $(-1.33 \%, p<0.001)$ and population density $\left(4.5^{*} 10-3 \%, p<0.01\right)$. In Nepal, TB CNR were associated with population sex ratio $(1.54 \%, p<0.01)$, facility density $(-0.19 \%, p<0.05)$ and treatment success rate $(-3.68 \%, p<0.001)$. Finally, TB CNR in Pakistan were found significantly associated with testing rate $(0.08 \%, p<$ $0.001)$, positivity rate $(4.29, p<0.001)$, proportion of bacteriologically confirmed cases $(-1.45, p<0.001)$, vaccination coverage $(1.17 \%, p<0.001)$ and facility density $(20.41 \%, p<0.001)$.

(Continued on next page)
\end{abstract}

* Correspondence: m.v.gurp@kit.nl

${ }^{1}$ KIT Royal Tropical Instituter, Amsterdam, Netherlands

Full list of author information is available at the end of the article

C C The Author(s). 2020 Open Access This article is licensed under a Creative Commons Attribution 4.0 International License, which permits use, sharing, adaptation, distribution and reproduction in any medium or format, as long as you give appropriate credit to the original author(s) and the source, provide a link to the Creative Commons licence, and indicate if changes were made. The images or other third party material in this article are included in the article's Creative Commons licence, unless indicated otherwise in a credit line to the material. If material is not included in the article's Creative Commons licence and your intended use is not permitted by statutory regulation or exceeds the permitted use, you will need to obtain permission directly from the copyright holder. To view a copy of this licence, visit http://creativecommons.org/licenses/by/4.0/ The Creative Commons Public Domain Dedication waiver (http://creativecommons.org/publicdomain/zero/1.0/) applies to the data made available in this article, unless otherwise stated in a credit line to the data. 
(Continued from previous page)

Conclusion: Subnational TB CNRs are more likely reflective of TB programme efforts and access to healthcare than TB burden. TB CNRs are better used for monitoring and evaluation of TB control efforts than the TB epidemic. Using spatial analytical techniques and profiling can help identify areas where TB is underreported. Applying these techniques routinely in the surveillance facilitates the use of TB CNRs in program planning.

Keywords: Tuberculosis, Case notification, Spatial analysis, GIS, Access to healthcare

\section{Background}

Tuberculosis (TB) is an infectious respiratory disease which affects millions of people all over the world, but overwhelmingly affects the most vulnerable, hard to reach and socioeconomically disadvantaged people [1] . Despite efforts to drastically reduce the burden of TB, it remains within the top ten causes of deaths worldwide and outranks HIV/AIDS as one of the leading causes of death from an infectious disease [2]. In 2017, an estimated 10.0 million people fell ill from TB. However, only 6.4 million were notified to the national authorities. This means that an estimated 3.6 million people with TB were either not detected by the health system or not notified to the local authorities, and therefore missed by the formal health systems [2]. Many of these missing people with TB do not receive the care they need, leaving them vulnerable to develop severe and potentially fatal infections as well as being a potential source of transmission to those around them [1-3].

There are several barriers that TB patients may encounter which causes them to not be diagnosed or notified by the health systems. These barriers are well described by Uplekar et al. and others [4-11]. First of all, the patient needs to recognize the symptoms, but due to misperceptions, lack of knowledge or even social or internalized stigma, the patient might fail to do so [4-6]. Secondly, the patient needs to seek healthcare which can be compromised by distance to health facilities or transportation costs, loss of wages, costs for diagnosis and treatment and the perception of poor quality services $[4,7,8]$. Thirdly, health workers might fail to recognize the symptoms due to lack of training or lack of human resources $[4,9]$. Fourth, the TB patient must be diagnosed as such, which can be complicated by insensitive screening and diagnostic tests, delay between testing and diagnosis that leads to loss to follow-up, or the inability for the individual with suspected TB to produce sputum $[4,10]$. Fifth, the patient with TB might not initiate treatment due to direct and indirect treatment costs, geographical access to TB services, inadequate knowledge of the importance of timely treatment and stigma [11]\{Citation\}. Finally, due to poor knowledge of reporting procedures of the health care provider or poor engagement with the private health care sector,
TB patients started on treatment might not be notified to the authorities [11].

TB case notification rates (CNR) are geographically heterogeneous [12-15]. Geographic variations in the presence of risk populations, TB transmission and burden are potential drivers of geographic variations in TB CNR. In Portugal for example, clusters of TB were associated with higher HIV/AIDS incidence, household crowding and incarceration [16]. Whereas in Brazil, higher rates of $\mathrm{TB}$ were associated with poor economic conditions, non-white population, urbanization and household crowding [17].

However, TB CNR are also a function of TB control efforts (i.e. the extent to which the health system effectively reaches out, diagnoses and notifies people with TB) and are therefore not necessarily an appropriate indicator of TB incidence. TB CNR can be only used as an indicator of TB incidence in places with a strong control program. A strong control program should take into account the subnational variation in TB burden and tailor its control efforts to the local epidemic [18].

It is our hypothesis that TB CNRs are only reflective of TB incidence in places where the TB control efforts are tailored to the local epidemic. Nonetheless, TB CNRs are often used as a proxy for TB incidence in the absence of a more reliable indicator of $\mathrm{TB}$ burden. If $\mathrm{TB}$ CNRs are used for the allocation of resources, we need a better understanding of what is driving the case notification rates. Therefore, the objective of this study is to gain better understanding of the drivers of subnational variations in $\mathrm{TB}$ notification rates in three South Asian countries with intermediate to high TB burden; Bangladesh, Nepal and Pakistan. The aim is to use spatial analytical techniques and profiling to gain better understanding of sociodemographic, health and programmatic indicators that underlie spatial variation of TB case notification rates.

\section{Methods \\ Setting}

This study uses aggregated subnational data from Bangladesh, Nepal and Pakistan. These countries were purposely selected based on the availability of recent subnational data on administrative areas (i.e. spatial data), TB notification, TB program efforts and indicators of demography and health; as well as their geographical 
proximity and thus similarities in geographic context. The study focusses on TB notification data from 2014 and 2015.

\section{Data}

Data on TB case notification and programmatic indicators routinely collected by the National Tuberculosis Programs (NTPs) of Bangladesh (2015), Nepal (2014) and Pakistan (2015) were obtained for the most recent and complete year. Additional data on demography and health were derived from publicly available reports, such as the Demographic and Health Survey (DHS), Multiple Indicator and Cluster Survey (MICS), population census reports and statistical yearbooks [19-31] . These reports were collected online from governmental websites such as the USAID and the Bureau of Statistics of each country [32-35] . Only reports with subnational data were included and reports prior to 2010 were excluded from this study. One dataset was made per country, which included all available data on district level or higher, leading to three datasets: one dataset covering 64 administrative units of Bangladesh, one dataset covering 75 administrative units of Nepal and one dataset covering 142 administrative units of Pakistan.

To be able to map and visualise TB indicators, spatial data files of the respective administrative boundaries for each of the three countries were obtained from online spatial data repositories [36-38]. As subnational boundaries and administrative units change throughout the years, adjustments to the spatial data files were made (i.e. merging of 2 administrative units into 1) to ensure that the spatial data is the same as the TB reporting units.

\section{Variables}

Subnational, annual TB case notification rates were used as the primary outcome variable for all analyses. It is defined as the number of reported cases per 100,000 population. It includes all reported cases, independent of the type of TB, the diagnostic method that had been used, or the patient's TB history [39].

The covariates that were used for this study were selected foremost because of their known association to TB burden or TB programme performance, but also on the availability of these indicators in public reports. The covariates that were used for this study can be grouped into four broader themes. An overview of all covariates and their definitions can be found in Table 1.

(1) Access to healthcare; the TB case notification rate tends to be higher in areas with better access to healthcare [40-42].
Table 1 Defintions of covariates

\begin{tabular}{|c|c|}
\hline Theme Covariate $^{\mathbf{a}}$ & Definition \\
\hline \multicolumn{2}{|l|}{ Access to healthcare } \\
\hline $\begin{array}{l}\text { Health facility } \\
\text { density }\end{array}$ & Number of health facilities per 100,000 population. \\
\hline $\begin{array}{l}\text { Vaccination } \\
\text { coverage }\end{array}$ & $\begin{array}{l}\text { Percentage of fully immunized children between } \\
12 \text { and } 23 \text { months. }\end{array}$ \\
\hline $\begin{array}{l}\text { Under-five } \\
\text { mortality rate }\end{array}$ & $\begin{array}{l}\text { Number of deaths of children under five per } 1000 \\
\text { live births. }\end{array}$ \\
\hline \multicolumn{2}{|c|}{ Socioeconomic status } \\
\hline $\begin{array}{l}\text { Poverty } \\
\text { headcount ratio }\end{array}$ & $\begin{array}{l}\text { Percentage of the total population living below the } \\
\text { national poverty line. }\end{array}$ \\
\hline Literacy rate & $\begin{array}{l}\text { Percentage of the population older than } 15 \text { who } \\
\text { can read and write. }\end{array}$ \\
\hline \multicolumn{2}{|c|}{ Demography \& key populations } \\
\hline Sex ratio & Number of males per 100 females. \\
\hline $\begin{array}{l}\text { Elderly } \\
\text { population }\end{array}$ & Percentage of population over 65 years of age. \\
\hline Ageing index & $\begin{array}{l}\text { Number of persons aged } 60 \text { or over per } 100 \\
\text { persons under the age of } 15 .\end{array}$ \\
\hline Stunting & $\begin{array}{l}\text { Percentage of children under five with a height-for- } \\
\text { age } z \text {-score below }-2 \text { standard deviations, from the } \\
\text { median of the reference population. }\end{array}$ \\
\hline $\begin{array}{l}\text { Migrant } \\
\text { distribution }\end{array}$ & $\begin{array}{l}\text { Percentage of total internal migrant population per } \\
\text { area. }\end{array}$ \\
\hline Miners & $\begin{array}{l}\text { Percentage of wage earners in mining industry/ } \\
\text { total population in mining and quarrying industry. }\end{array}$ \\
\hline $\begin{array}{l}\text { Population } \\
\text { density }\end{array}$ & Number of persons per square kilometre. \\
\hline Security & $\begin{array}{l}\text { Districts of Pakistan that were frequently reported } \\
\text { as "insecure". }\end{array}$ \\
\hline \multicolumn{2}{|c|}{ Quality of TB diagnostic and treatment services } \\
\hline Testing rate & $\begin{array}{l}\text { Number of persons tested for TB per 100,000 } \\
\text { population. }\end{array}$ \\
\hline $\begin{array}{l}\text { Test positivity } \\
\text { rate }\end{array}$ & $\begin{array}{l}\text { Percentage of tested individuals with a positive test } \\
\text { result. }\end{array}$ \\
\hline $\begin{array}{l}\text { Bacteriologically } \\
\text { diagnosed }\end{array}$ & $\begin{array}{l}\text { Proportion of total cases with a bacteriologically } \\
\text { confirmed test result. }\end{array}$ \\
\hline $\begin{array}{l}\text { Treatment } \\
\text { success rate }\end{array}$ & $\begin{array}{l}\text { Proportion of notified cases who have completed } \\
\text { their treatment. }\end{array}$ \\
\hline
\end{tabular}

${ }^{a}$ Not all covariates were available for all countries

(2) Socioeconomic status (SES); TB is associated with the socially and economically disadvantaged [17, 43].

(3) Demography and key populations; Certain demographic and socio-economic key populations are known to have an increased risk of developing clinical TB, these include: miners, migrants, males, the malnourished and the elderly [44-48].

(4) Quality of TB treatment and diagnostic services; The ability of the healthcare system to detect and treat TB patients is associated to various performance indicators $[48,49]$. 
In order to link the covariate data to the units in the spatial data files, every geographical unit was assigned an unique identifier in the form of a numerical code. The same code was given to the spatial information belonging to that geographical unit. This way, the compiled subnational data were merged with the spatial information and subsequently visualized in GIS software.

\section{Statistical analysis \\ Spatial autocorrelation}

The global univariable Moran's I was used to test for the presence of spatial clustering (spatial autocorrelation) in the TB case notification rate at subnational level. In addition, Local Indicators of Spatial Autocorrelation (LISA) were calculated in order to identify and locate clusters of districts with a relatively high or low TB case notification rate. A first order queen contiguity connectivity matrix was used to define neighbouring districts. These statistics give valuable information about the independency (i.e. absence of spatial dependency) of observations, an important assumption in regression analyses [50].

\section{Univariable and multivariable analyses}

Generalized linear models (GLM) with log transformed outcome variable (TB CNR) were fitted to the data for the univariable and multivariable analyses - separately for each country - based on the fit and nature of the data, as disease rates often follow a log-normal distribution [51]. A poisson and negative binomial model were also considered as these are frequently used to model disease rates, but the lognormal model provided a better fit for all three countries. First, univariable analyses were conducted for each covariate to assess the strength and direction of the association. Next, all variables were included in a multivariable GLM Finally, simultaneous autoregressive (SAR) models were fitted to the data to account for unexplained spatial autocorrelation in the residuals of the multivariable GLM. This model uses a spatially correlated error structure based on a contiguity weights matrix taking into account only directly adjacent spatial neighbours (i.e. shared borders). The reported coefficients are exponentiated and reflect percentage change in TB CNR. All models are reported with corresponding 95\% confidence interval (CI) and p-values, as well as the global Moran's I statistic with corresponding $p$-value for the residuals of the multivariable models.

Pearson's correlation coefficients were calculated for all covariates before multivariable modelling. If two variables were correlated (i.e. correlation coefficient exceeding 0.7 ), one of the variables was excluded from further analysis. The variable to be excluded was determined by the number of correlations, where the variable with highest number of correlations was excluded. In case both variables had equal numbers of correlations than the variable with a non-significant result in the univariable analysis was excluded.

Data analyses were performed using GeoDa version 1.8.16.4 for the assessment of spatial autocorrelation, RStudio version 1.0.143 for all other statistical analyses and QGIS version 2.18.4 for the geographical visualization of the data [52-54].

\section{Results}

\section{Descriptive analysis}

A total of 205,98; 37,025 and 326,152 people were diagnosed with TB and notified in Bangladesh (2015), Nepal (2014) and Pakistan (2015) respectively. Subnational TB case notifications per hundred thousand population ranged from 50 to 187 in Bangladesh, from 31 to 227 in Nepal and from 9 to 689 in Pakistan (Table 2, 3 and 4).

Spatial clustering of TB case notification rates was observed in Nepal (Moran's I: 0.52, $p$-value < 0.001, Fig. 1). In the northern mountainous region of Nepal clusters of low notification rates (cold spots) were observed whereas in the lower "Terai" region in the south of Nepal several clusters of high notification rates (hot spots) were identified (Fig. 2) Moderate spatial clustering of TB case notification rates were observed in Bangladesh (Moran's I: 0.23 , $p$-value $<0.01$, Fig. 3), with one larger hot spot in the eastern division Sylhet and two small cold spots in Rajshahi and Dhaka divisions (Fig. 4).

Moderate spatial clustering was also observed for Pakistan (Moran's I: 0.23, $p$-value $<0.001$, Fig. 5), with a large cold spot covering almost the entire province of Balochistan and one major hot spot in Punjab province (Fig. 6).

\section{Statistical results}

Tables 5, 6 and 7 show the results of the univariable, non-spatial multivariable and spatial multivariable models of the natural logarithm of the TB case notification rate for Bangladesh, Nepal and Pakistan.

Based on the correlation matrices (Additional file 1) and the univariable analyses, the following covariates were excluded prior to multivariable modelling: facility density and migrant population (Bangladesh), miners and under 5 mortality rate (Nepal), and literacy rate (Pakistan).

\section{Bangladesh}

The spatial GLM model for Bangladesh showed that TB CNR is positively associated to population density $(\beta=$ 4.5e-3; 95\%CI: $1.7 \mathrm{e}-3-7.3 \mathrm{e}-3)$, testing rate $(\beta=0.06, \mathrm{CI}$ : $0.06-0.07$ ) and positivity rate ( $\beta=14.44$, CI: $12.44-16.48$ ). Furthermore, the model suggests that an increase in the proportion of bacteriologically confirmed cases is associated with a decrease in TB case notification rate of 1.33\% 
Table 2 Descriptive statistics for Bangladeshi districts

\begin{tabular}{|c|c|c|c|c|c|c|c|c|}
\hline \multirow[t]{2}{*}{ Variable } & \multirow[t]{2}{*}{$\mathrm{N}$} & \multirow[t]{2}{*}{ Mean $^{\mathbf{a}}$} & \multirow[t]{2}{*}{ SD } & \multirow[t]{2}{*}{ Min } & \multirow[t]{2}{*}{ Max } & \multicolumn{2}{|c|}{ Missing } & \multirow[t]{2}{*}{ National ${ }^{\mathbf{b}}$} \\
\hline & & & & & & N & $\%$ & \\
\hline Population & 64 & $2,488,828$ & $2,039,092$ & 449,100 & $14,386,878$ & 0 & 0.0 & $159,284,969$ \\
\hline Case notification & 64 & 3219 & 3291 & 455 & 23,686 & 0 & 0.0 & 205,985 \\
\hline Case notification rate & 64 & 124 & 33 & 50 & 187 & 0 & 0.0 & 129 \\
\hline \multicolumn{9}{|l|}{$\underline{\text { Healthcare access }}$} \\
\hline Facility density (per 100,000 population) & 64 & 0.9 & 0.9 & 0.3 & 5.6 & 0 & 0.0 & 0.7 \\
\hline Under-five mortality rate (per 1000 live births) & $64^{c}$ & 46 & 9 & 35 & 67 & 0 & 0.0 & N/A \\
\hline Vaccination coverage (\%) & 64 & 87.2 & 3.8 & 76.4 & 94.5 & 0 & 0.0 & N/A \\
\hline \multicolumn{9}{|l|}{ Socioeconomic status } \\
\hline Poverty headcount ratio (\%) & 64 & 32.3 & 12.1 & 3.6 & 63.7 & 0 & 0.0 & N/A \\
\hline Literacy rate (\%) & 64 & 54.7 & 7.8 & 37.5 & 73.7 & 0 & 0.0 & N/A \\
\hline \multicolumn{9}{|l|}{ TB programme efforts } \\
\hline Bacteriologically confirmed (\%) & 64 & 74.1 & 7.3 & 56.9 & 89.1 & 0 & 0.0 & 72.5 \\
\hline Test positivity rate (\%) & 64 & 6.3 & 1.4 & 3.3 & 10.7 & 0 & 0.0 & 6.5 \\
\hline Test rate (per 100,000 population) & 64 & 1199 & 352 & 569 & 2015 & 0 & 0.0 & 1145 \\
\hline Treatment success rate (\%) & 64 & 94.4 & 2.3 & 87.1 & 99.2 & 0 & 0.0 & 94.5 \\
\hline \multicolumn{9}{|l|}{ Demography } \\
\hline Stunting (\%) & 64 & 41.2 & 7.0 & 27.7 & 55.9 & 0 & 0.0 & N/A \\
\hline Sex ratio (male: female) & 64 & 99.2 & 4.8 & 90.2 & 119.3 & 0 & 0.0 & N/A \\
\hline Population density (per km²) & 64 & 1108 & 1038 & 86 & 8111 & 0 & 0.0 & \\
\hline Elderly population (\%) & 64 & 7.8 & 1.3 & 4.8 & 11.3 & 0 & 0.0 & N/A \\
\hline Migrant population (\%) ${ }^{c}$ & 64 & 0.06 & 0.06 & 0.01 & 0.39 & 0 & 0.0 & N/A \\
\hline
\end{tabular}

${ }^{\mathrm{a}}$ Unweighted mean of districts. ${ }^{\mathrm{b}}$ Weighted national average. ${ }^{\mathrm{c}}$ Data were available on the first administrative level only N/A National average could not be calculated due to lack of denominator

(CI: - $1.65--1.01)$. The model fully accounted for spatial autocorrelation in TB CNR (Moran's I: $-0.07, p$-value $=$ $0.28)$, therefore no SAR model was fitted.

\section{Nepal}

The residuals of the non-spatial multivariable model for Nepal were found to spatially auto correlate (Moran's I: $0.17, p$-value $<0.01$ ) and a spatial model correcting for the special dependencies was computed. The spatial multivariable model shows that facility density is inversely associated to the TB CNR, where an increase of one unit in facility density is associated with a decrease of the TB CNR of $0.19 \%$ (CI: - $0.37-0.01$ ). Furthermore, an increase of one unit in sex ratio is associated with an increase in TB CNR of $1.54 \%$ (CI: 0.40-2.69). Treatment success rate $(\beta:-3.68, \mathrm{CI}:-5.27-2.08)$ and stunting ( $\beta$ :-1.88, CI: $-3.15--0.60)$, are both inversely associated to TB CNR in the spatial model. The spatial model accounted for all spatial autocorrelation (Moran's I: $-0.02, p$-value $=0.44$ )

\section{Pakistan}

According to the spatial multivariable model TB CNR (which was necessary with a Moran's I: 0.11 after the
GLM) was found positively associated with testing rate $(\beta=0.08, C I: 0.05-0.10)$, test positivity rate $(\beta=4.29, \mathrm{CI}$ : $2.73-5.87)$, proportion bacteriologically diagnosed $(\beta=-$ 1.45, CI: $-2.02--0.88)$, vaccination coverage $(\beta=1.17$, CI: $0.61-1.72)$ and facility density $(\beta=20.41, C I: 8.42-$ 33.72). The SAR model fully accounted for the spatial autocorrelation of the TB CNR (Moran's I: $-0.04, p$ value $=0.14)$.

\section{Discussion}

From TB prevalence studies we know that there is a gap between TB notification and TB burden. Onozaki et al. assessed national TB prevalence surveys in Asia from 1990 to 2012 and found the TB prevalence to be twice as high as the number of notified cases [55]. Yet TB notification rates are often used as a measure of TB incidence, making it imperative that we have a better understanding of the drivers of TB notification rates.

The data and results presented in this paper show that TB case notifications across the three countries analysed are spatially heterogeneous and spatially clustered. The positive association between population density in Bangladesh and sex ratio in Nepal suggest that part of the variation in TB CNR can be explained by proxies for 
Table 3 Descriptive statistics for Nepali districts

\begin{tabular}{|c|c|c|c|c|c|c|c|c|}
\hline \multirow[t]{2}{*}{ Variable } & \multirow[t]{2}{*}{ N } & \multirow[t]{2}{*}{ Mean $^{a}$} & \multirow[t]{2}{*}{ SD } & \multirow[t]{2}{*}{ Min } & \multirow[t]{2}{*}{ Max } & \multicolumn{2}{|c|}{ Missing } & \multirow[t]{2}{*}{ National $^{\mathbf{b}}$} \\
\hline & & & & & & $\bar{N}$ & $\%$ & \\
\hline Population & 75 & 364,160 & 304,925 & 5284 & $1,931,225$ & 0 & 0.0 & $27,311,978$ \\
\hline Case notification & 75 & 494 & 572 & 4 & 3642 & 0 & 0.0 & 37,025 \\
\hline Case notification rate & 75 & 110 & 49 & 31 & 227 & 0 & 0.0 & 136 \\
\hline \multicolumn{9}{|l|}{ Healthcare access } \\
\hline Facility density (per 100,000 population) & 75 & 98.9 & 73.6 & 24.7 & 530.0 & 0 & 0.0 & 65.6 \\
\hline Under-five mortality rate (per 1000 live births) & $75^{c}$ & 64 & 9 & 55 & 82 & 0 & 0.0 & N/A \\
\hline Vaccination coverage (\%) & $75^{c}$ & 88.9 & 4.7 & 79.8 & 97.4 & 0 & 0.0 & N/A \\
\hline \multicolumn{9}{|l|}{ Socio-economic status } \\
\hline Poverty headcount ratio (\%) & 75 & 27.7 & 13.4 & 4.0 & 64.1 & 0 & 0.0 & N/A \\
\hline Literacy rate (\%) & 75 & 58.1 & 10.6 & 34.6 & 87.3 & 0 & 0.0 & N/A \\
\hline \multicolumn{9}{|l|}{ Demography } \\
\hline Stunting (\%) & $75^{c}$ & 43.4 & 9.7 & 31.3 & 59.5 & 0 & 0.0 & N/A \\
\hline Sex ratio (male: female) & 75 & 92.7 & 9.0 & 76.0 & 127.3 & 0 & 0.0 & N/A \\
\hline Population density (per km²) & 75 & 312 & 590 & 3 & 4416 & 0 & 0.0 & N/A \\
\hline Ageing index (elders per 100 persons under 15$)^{d}$ & 74 & 16.3 & 6.1 & 6.2 & 35.5 & 1 & 1.3 & N/A \\
\hline Miners & $75^{c}$ & 1 & 0.5 & 0.3 & 1.7 & 0 & 0.0 & N/A \\
\hline Migrant distribution (\%) & $75^{c}$ & 35.9 & 5.0 & 26.0 & 39.3 & 0 & 0.0 & N/A \\
\hline \multicolumn{9}{|l|}{ TB programme efforts } \\
\hline Bacteriologically confirmed (\%) & 75 & 72.2 & 12.8 & 22.2 & 100.0 & 0 & 0.0 & 70.3 \\
\hline Treatment success rate (\%) & 74 & 92.4 & 4.8 & 81.7 & 100.0 & 1 & 1.3 & 90.7 \\
\hline
\end{tabular}

${ }^{a}$ Unweighted mean of districts. ${ }^{b}$ Weighted national average. ${ }^{c}$ Data were available on the regional level only

N/A: National average could not be calculated due to lack of denominator. ${ }^{d}$ The number of elders per 100 persons younger than 15

Table 4 Descriptive statistics for Pakistani districts

\begin{tabular}{|c|c|c|c|c|c|c|c|c|}
\hline \multirow[t]{2}{*}{ Variable } & \multirow[t]{2}{*}{ N } & \multirow[t]{2}{*}{ Mean $^{\mathbf{a}}$} & \multirow[t]{2}{*}{ SD } & \multirow[t]{2}{*}{ Min } & \multirow[t]{2}{*}{ Max } & \multicolumn{2}{|c|}{ Missing } & \multirow[t]{2}{*}{ National $^{\mathbf{b}}$} \\
\hline & & & & & & $\mathrm{N}$ & $\%$ & \\
\hline Population & 142 & $1,310,675$ & $1,686,617$ & 26,265 & $14,040,575$ & 0 & 0.0 & $186,115,787$ \\
\hline Case notification & 142 & 2297 & 3286 & 21 & 22,185 & 0 & 0.0 & 326,153 \\
\hline Case notification rate & 142 & 147 & 93 & 9 & 689 & 0 & 0.0 & 175 \\
\hline \multicolumn{9}{|l|}{ Healthcare access } \\
\hline Facility density (per 100,000 population) & 132 & 1.3 & 1.0 & 0.4 & 8.9 & 10 & 7.0 & 0.8 \\
\hline Under-five mortality rate (per 1000 live births) & $122^{c}$ & 95.6 & 15.7 & 43.0 & 111.0 & 20 & 14.1 & N/A \\
\hline Vaccination coverage (\%) & 122 & 69.9 & 23.0 & 3.0 & 99.0 & 20 & 14.1 & N/A \\
\hline \multicolumn{9}{|l|}{$\underline{\text { Socio-economic status }}$} \\
\hline Poverty headcount ratio (\%) & 114 & 45.3 & 24.2 & 3.7 & 96.4 & 28 & 19.7 & N/A \\
\hline Literacy rate (\%) & 122 & 49.9 & 14.5 & 19.6 & 85.0 & 20 & 14.1 & N/A \\
\hline \multicolumn{9}{|l|}{ Demography } \\
\hline Stunting (\%) & $92^{c}$ & 44.1 & 7.7 & 22.2 & 56.7 & 50 & 35.2 & N/A \\
\hline Migrant distribution (\%) & $115^{c}$ & 28.5 & 28.0 & 0.7 & 67.8 & 27 & 19.0 & N/A \\
\hline \multicolumn{9}{|l|}{ TB programme efforts } \\
\hline Bacteriologically confirmed (\%) & 141 & 54.0 & 15.3 & 6.3 & 100.0 & 1 & 0.7 & 52.0 \\
\hline Test positivity rate (\%) & 139 & 14.7 & 6.6 & 1.9 & 41.7 & 3 & 2.1 & 13.8 \\
\hline Test rate (per 100,000 population) & 139 & 478 & 498 & 40 & 4369 & 3 & 2.1 & 542 \\
\hline Treatment success rate (\%) & 141 & 92.6 & 5.7 & 75.0 & 100.0 & 1 & 0.7 & 91.8 \\
\hline
\end{tabular}

${ }^{a}$ Unweighted mean of districts. ${ }^{b}$ Weighted national average. ${ }^{c}$ Data were available on the first administrative level only N/A National average could not be calculated due to lack of denominator 


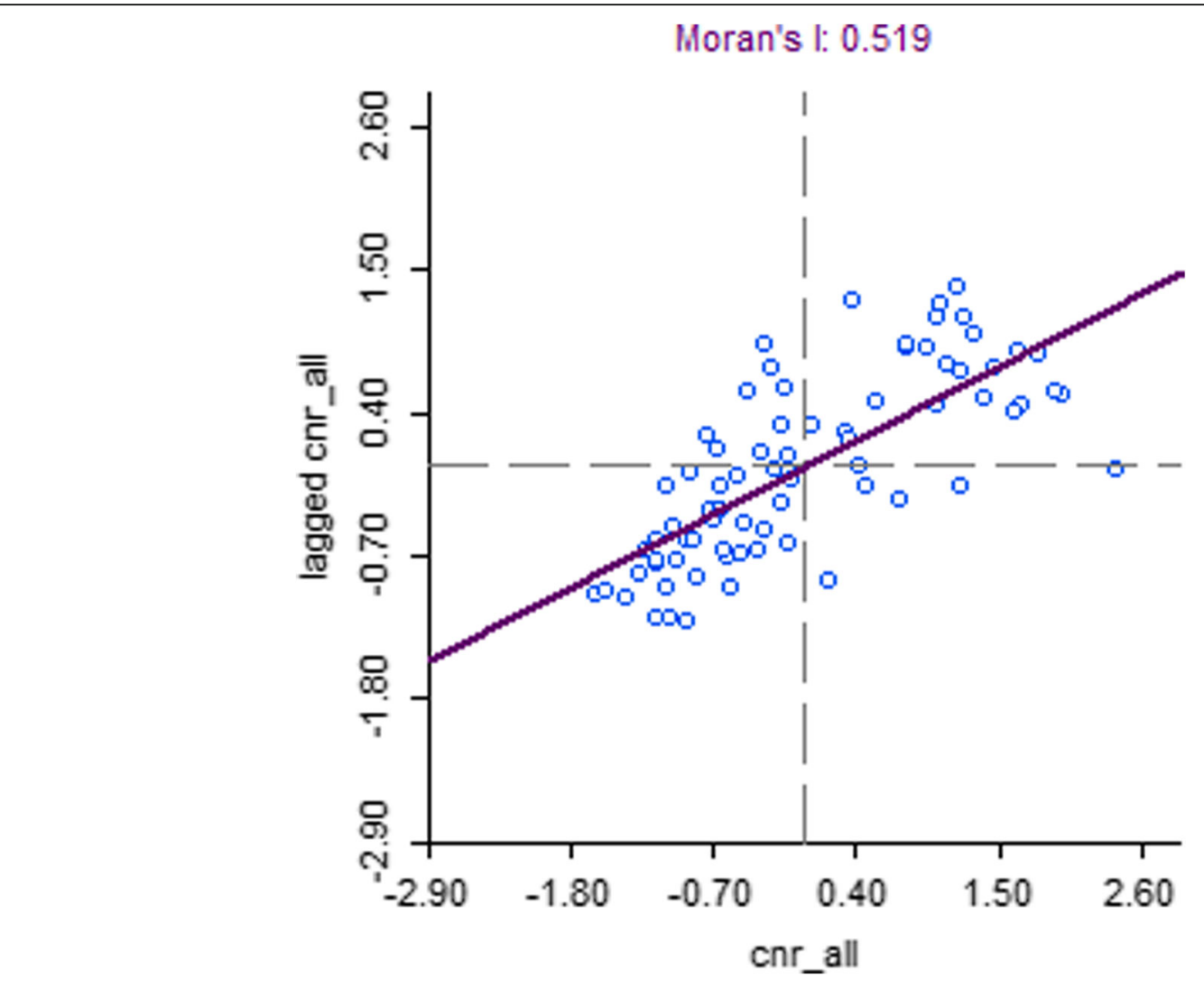

Fig. 1 Moran's I plot showing the strength of spatial autocorrelation of TB CNR (2014), Nepal

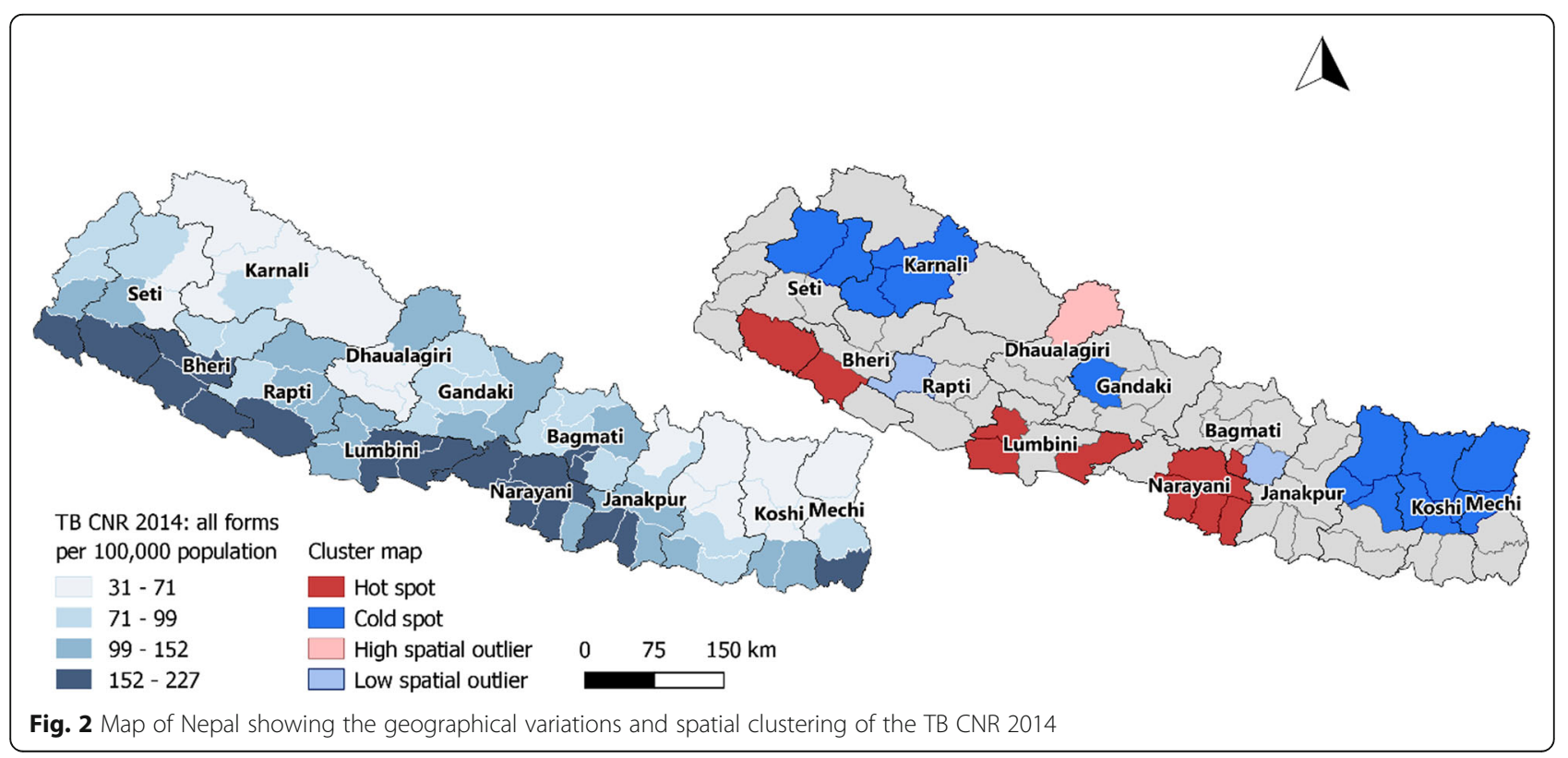




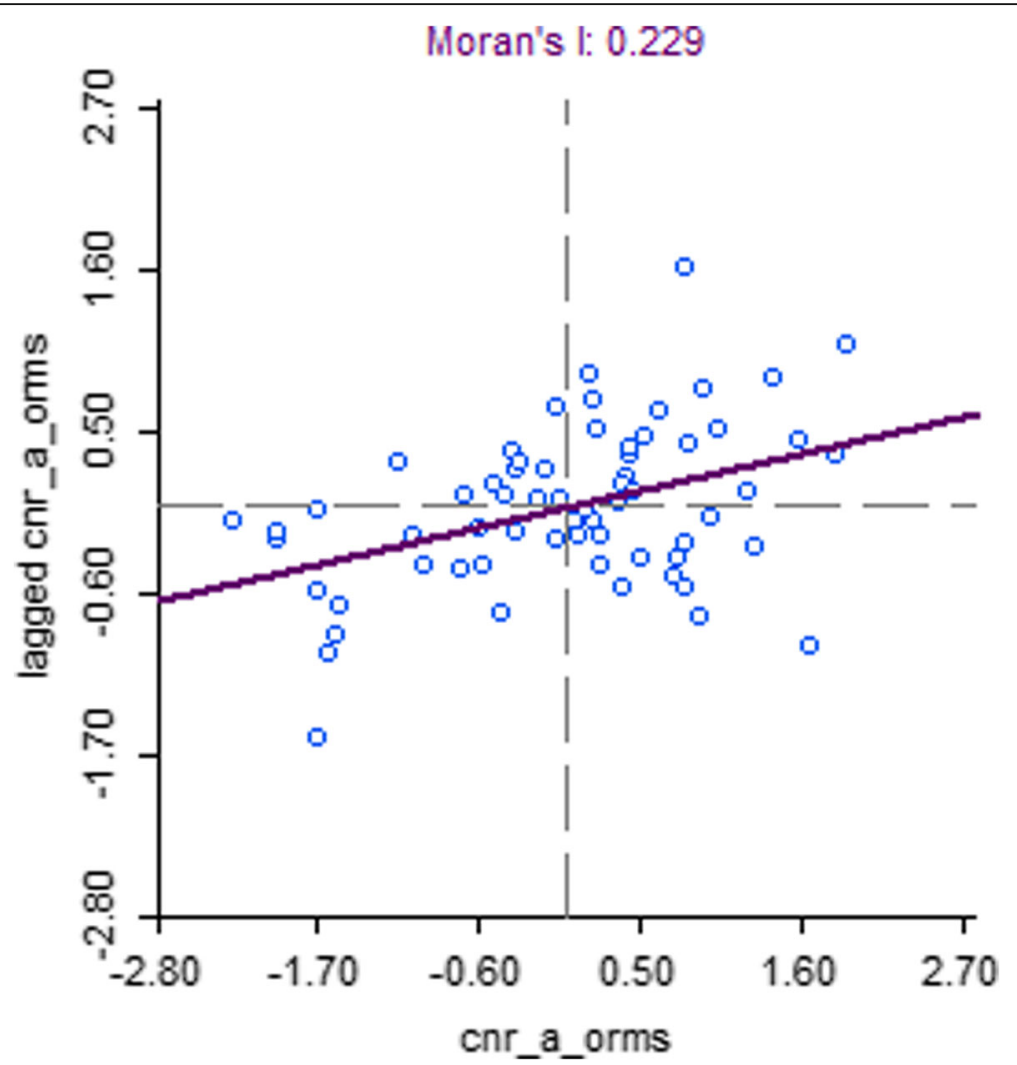

Fig. 3 Moran's I plot showing the strength of spatial autocorrelation of TB CNR (2015), Bangladesh

TB risk. In Bangladesh an increase in population density is positively associated with TB CNR (B:4.5e-3, 95\%CI: $1.7 \mathrm{e}-3-7.3 \mathrm{e}-3)$, a higher population density is indicative of more crowding which increases transmission of TB [56]. Crowding has been associated with increased risk of TB in Bangladesh in both adults and children $[57,58]$. Furthermore, a positive association between sex ratio and TB CNR in Nepal (B:1.54, 95\%CI:0.40-2.69) shows that more TB patients are diagnosed in districts with more men. This is line with findings of the TB prevalence survey, which found a much higher prevalence in men [59].

However, the models also suggest that part of the variation in TB CNR can be explained by programmatic factors. TB CNR is inversely associated with the proportion of TB patients with a bacteriologically confirmation in both Bangladesh (B:-1.33, 95\%CI:-.65 - -1.01) and Pakistan (B:-1.45, 95\%CI: - $2.02--0.88$ ). One explanation is that more sensitive diagnostic methods can result in a reduction of clinically diagnosed pulmonary $\mathrm{TB}$, which may cause a reduction in the overall TB CNR [60].

The positive association between testing rate and $\mathrm{TB}$ CNR in Bangladesh (B:0.06, 95\%CI:0.06-0.07) and Pakistan (B:0.08, 95\%CI:0.05-0.10) suggests that more testing yields higher notification. In a well-adjusted system, the level of testing is direct response to the local
TB burden. But the positive association between test positivity rates in both countries (Bangladesh: B:14.44, 95\%CI:12.44-16.48, Pakistan B:4.29, 95\%CI:2.73-5.87) suggests otherwise. When the testing rate increases, one would expect the positivity rate to decrease or remain stable. The increasing test positivity rate suggests that the current level of testing does not meet the local need for testing or that testing efforts may be targeted towards populations more likely to suffer from TB.

The positive association between TB CNR with facility density (B:20.41, 95\%CI:8.42-33.72) and vaccination coverage (B:1.17, 95\%CI:0.61-1.72) in Pakistan substantiate the results above. Facility density and vaccination coverage are both indicative of better access to health care and improved uptake of health services [61].

In contrast with the findings above, facility density is inversely associated with TB CNR in Nepal (B:-0.19, 95\%CI:-0.37 - -0.01). One explanation is that in areas with very low population numbers (such as the hilly and mountainous regions in Nepal), the facility density is likely to be very high. Likewise, in highly urbanized areas (e.g. Kathmandu) the facility to population ratio can be very low due to the high population denominator. Although the placement of health facilities takes into account population density and the unmet need of the population, the facility to population ratio calculated on 


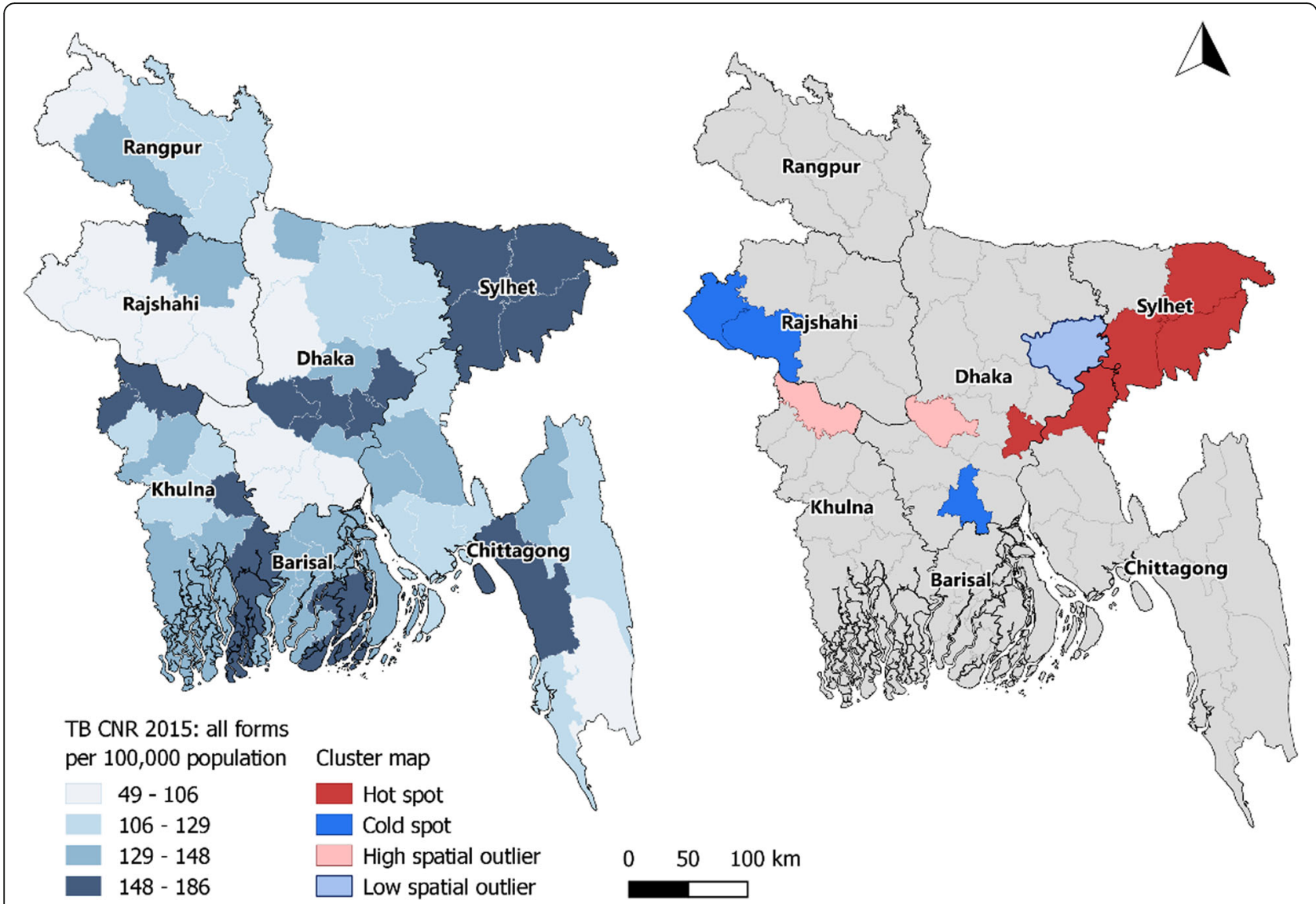

Fig. 4 Map of Bangladesh showing the geographical variations and spatial clustering of the TB CNR 2015

district level does not reflect this and might therefore not be the right metric to assess access to healthcare on a district level.

The inverse association between treatment success rate and TB CNR in Nepal (B:-3.68, 95\%CI:-5.27 - -2.08) suggests that higher notification rates negatively affect case management, possibly due a higher burden on the health system to follow-up on TB patients or to provide the required medication.

The TB CNR decreases with 1.88\% (95\%CI: - 3.15 -0.60) with increasing prevalence of stunting (Nepal). Stunting is strongly associated with lower socioeconomic status and poor health, which increases the risk of TB, but in this case may reflect lower access to healthcare. This is in line with findings from the TB prevalence survey, where the proportion of TB patients not seeking care was higher among the poor [59].

Although the models largely agree with one another, we see differences in the associations between sociodemographic and access indicators with the CNR. This finding underscore that the results are to some extent influenced by country context, specifically health care infrastructure and TB epidemiology.

\section{Strengths and limitations}

We were able to combine data from multiple sources, hence capturing different dimensions of the same phenomenon as well as minimizing inadequacies that occur in data from a single source. Furthermore, the models are congruent in what they suggest and the strength and direction of the associations are also consistent between the models. These similarities between independent models decrease the likelihood of the observed associations being the result of chance. In addition, most of the spatial clustering is adjusted for in the final models.

The data that were used in this study were derived from various sources and were therefore available on different administrative levels and for different years. However, we expect demographic indicators such as poverty, migration and population size to remain stable over the course of three to 5 years or to grow proportionally over time. Although natural disasters and conflict are known to influence demographic indicators, these changes are often not reflected in district level population statistics as presented by national statistical offices which also cover a broader time frame. However, the possibility 


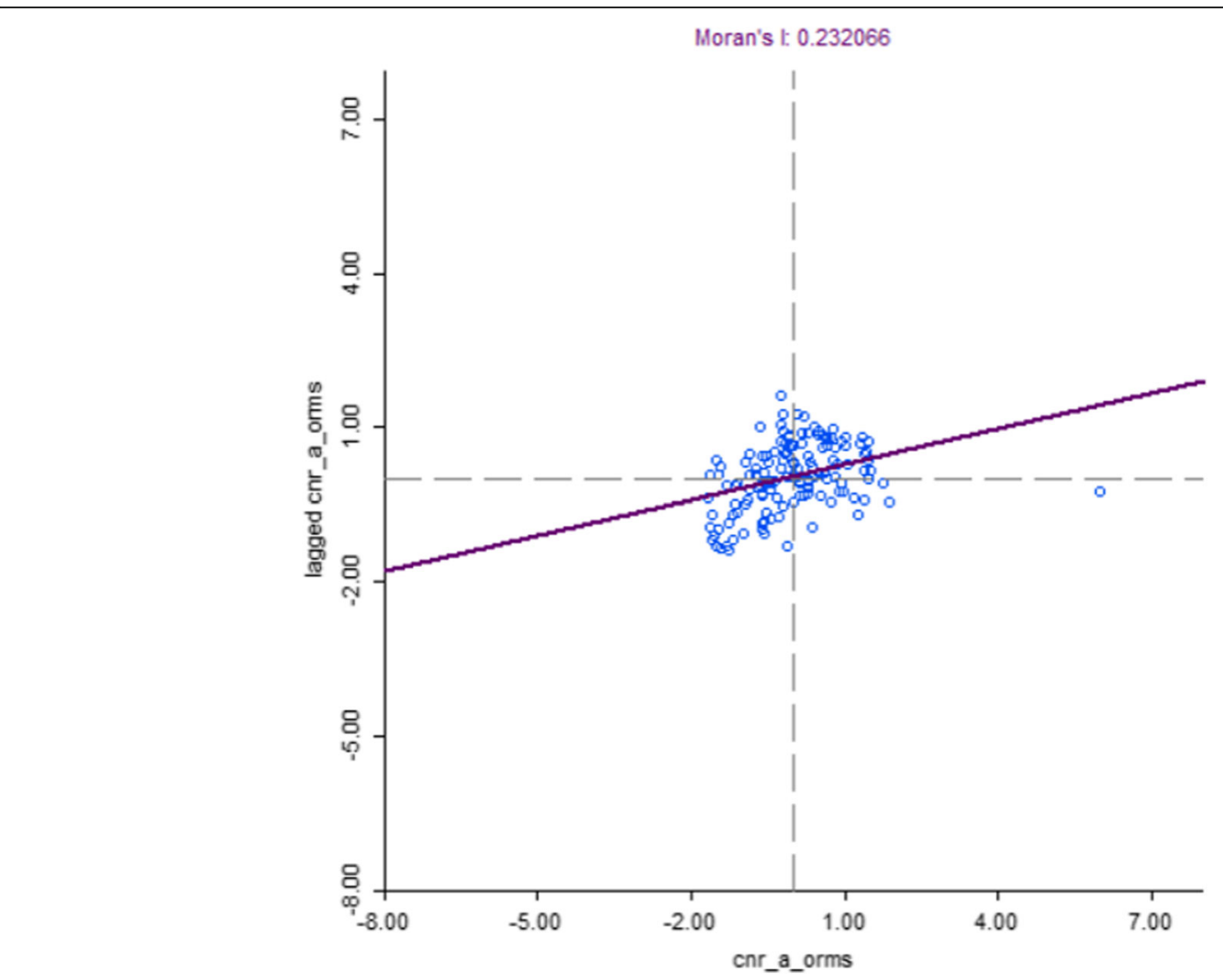

Fig. 5 Moran's I plot showing the strength of spatial autocorrelation of TB CNR (2015), Pakistan

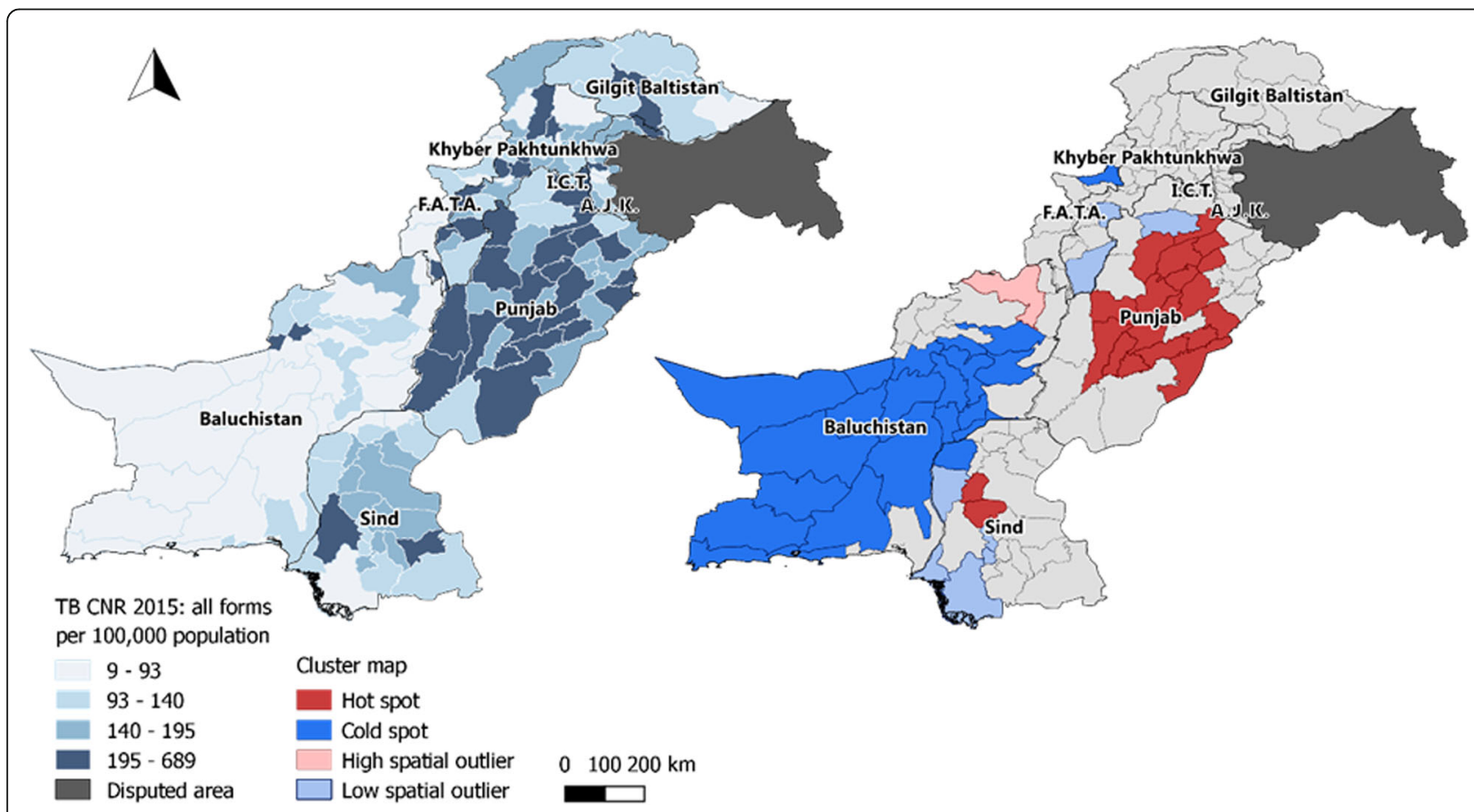

Fig. 6 Map of Pakistan showing the geographical variations and spatial clustering of the TB CNR 2015 
Table 5 Results of the univariable and multivariable analyses for Bangladesh and global Moran's I of the residuals of the multivariable model

\begin{tabular}{|c|c|c|c|c|}
\hline \multirow[t]{2}{*}{ Covariate } & \multicolumn{2}{|c|}{ Univariable } & \multicolumn{2}{|c|}{ Non-spatial multivariable ${ }^{\mathbf{a}}$} \\
\hline & $B$ & $\mathrm{Cl}$ & $B$ & $\mathrm{Cl}$ \\
\hline Constant & - & - & 52.12 & $9.74-261.59$ \\
\hline Population density & 0.01 & $-0.002-0.01$ & $4.5 e-3^{* *}$ & $1.7 e-3-7.3 e-3$ \\
\hline Bacteriologically diagnosed & $-1.51^{* *}$ & $-2.45--0.57$ & $-1.33^{* * *}$ & $-1.65--1.01$ \\
\hline Testing rate & $0.05^{* * *}$ & $0.03-0.07$ & $0.06^{* * *}$ & $0.06-0.07$ \\
\hline Positivity rate & $12.83^{* * *}$ & $7.97-8.52$ & $14.44^{* * *}$ & $12.44-16.48$ \\
\hline Facility density & 0.37 & $-7.17-8.51$ & - & - \\
\hline Treatment success rate & $5.87^{* * *}$ & $2.82-8.99$ & -0.25 & $-1.52-1.04$ \\
\hline Vaccination coverage & -1.22 & $-3.12-0.72$ & 0.34 & $-0.39-1.08$ \\
\hline Literacy rate & 0.23 & $-0.07-1.20$ & -0.2 & $-0.54-0.13$ \\
\hline Poverty headcount ratio & $-0.62^{*}$ & $-1.21--0.2$ & -0.05 & $-0.24-0.15$ \\
\hline Stunting & 0.56 & $-0.50-1.63$ & -0.02 & $-0.36-0.32$ \\
\hline Under-five mortality ratio & $1.15^{* *}$ & $0.31-1.99$ & -0.05 & $-0.38-0.27$ \\
\hline Sex ratio & 0.53 & $-1.01-2.09$ & 0.14 & $-0.58-0.86$ \\
\hline Elderly population & -1.83 & $-7.17-3.82$ & 1.11 & $-1.58-3.88$ \\
\hline Migrant distribution & 0.88 & $-0.32-2.10$ & - & - \\
\hline Global Moran's I of the residuals & & & -0.07 & \\
\hline$P$-value of global Moran's I & & & 0.28 & \\
\hline
\end{tabular}

${ }^{a}$ Generalized linear model for the natural logarithm of the TB case notification rate; not adjusted for spatial autocorrelation All coefficients $(B)$ are exponentiated and reflect percentage change in TB case notification rate

${ }^{*} p<0.05$, ** $p<0.01$, *** $p<0.001$

Table 6 Results of the univariable and multivariable analyses for Nepal and global Moran's I of the residuals of the multivariable models

\begin{tabular}{|c|c|c|c|c|c|c|}
\hline \multirow[b]{2}{*}{ Covariate } & \multicolumn{2}{|c|}{ Univariable } & \multicolumn{2}{|c|}{ Non-spatial multivariable ${ }^{\mathbf{a}}$} & \multicolumn{2}{|c|}{ Spatial multivariable ${ }^{\mathbf{b}}$} \\
\hline & $B$ & $\mathrm{Cl}$ & $B$ & $\mathrm{Cl}$ & $B$ & $\mathrm{Cl}$ \\
\hline Constant & - & - & & & & \\
\hline Facility density & $-0.29^{* * *}$ & $-0.42--0.16$ & -0.19 & $-0.39-0$ & $-0.19^{*}$ & $-0.37--0.01$ \\
\hline Sex ratio & 0.99 & $-0.18-2.18$ & $1.56^{*}$ & $0.31-2.83$ & $1.54^{* *}$ & $0.40-2.69$ \\
\hline Treatment success rate & $-5.19^{* * *}$ & $-6.95--3.40$ & $-3.66^{* * *}$ & $-5.38--1.91$ & $-3.68^{* * *}$ & $-5.27--2.08$ \\
\hline Stunting & $-1.83^{* * *}$ & $-2.83--0.83$ & $-1.89^{*}$ & $-3.27--0.48$ & $-1.88^{* *}$ & $-3.15--0.60$ \\
\hline Bacteriologically diagnosed & -0.63 & $-1.45-0.18$ & -0.32 & $-1.06-0.43$ & -0.31 & $-0.99-0.37$ \\
\hline Population density & $0.03^{* * *}$ & $0.01-0.05$ & 0 & $-0.02-0.01$ & 0 & $-0.02-0.01$ \\
\hline Migrant distribution & -0.43 & $-2.52-1.71$ & -1.31 & $-3.59-1.02$ & -1.36 & $-3.47-0.8$ \\
\hline Literacy rate & 0.04 & $-0.97-1.05$ & 1.21 & $-0.16-2.6$ & 1.16 & $-0.11-2.44$ \\
\hline Under-five mortality rate & 0.45 & $-0.68-1.60$ & & & & \\
\hline Poverty headcount ratio & $-0.89^{*}$ & $-1.57--0.04$ & 57.39 & $-41.65-324.53$ & 50.99 & $-39.55-277.15$ \\
\hline Ageing index & -1.07 & $-2.79-0.67$ & -0.58 & $-3.28-2.19$ & -0.56 & $-3.06-2.01$ \\
\hline Miners & $-20.88^{*}$ & $-35.76--2.54$ & & & & \\
\hline Vaccination coverage & -1.29 & $-3.48-0.95$ & -1.2 & $-3.45-1.1$ & -1.23 & $-3.29-0.88$ \\
\hline Global Moran's I of the residuals & & & 0.17 & & -0.02 & \\
\hline$P$-value of global Moran's I & & & 0.01 & & 0.44 & \\
\hline
\end{tabular}

a Generalized linear multivariable model for the natural logarithm of the TB case notification rate; not adjusted for spatial autocorrelation

${ }^{b}$ Simultaneous autoregressive multivariable model for the natural logarithm of the TB case notification rate; adjusted for spatial autocorrelation

All coefficients $(B)$ are exponentiated and reflect percentage change in TB case notification rate

${ }^{*} p<0.05,{ }^{* *} p<0.01,{ }^{* * *} p<0.001$ 
Table 7 Results of the univariable and multivariable analyses for Pakistan and global Moran's I of the residuals of the multivariable models

\begin{tabular}{|c|c|c|c|c|c|c|}
\hline \multirow[b]{2}{*}{ Covariate } & \multicolumn{2}{|c|}{ Univariable } & \multicolumn{2}{|c|}{ Non-spatial multivariable $^{\mathbf{a}}$} & \multicolumn{2}{|c|}{ Spatial multivariable ${ }^{\mathbf{b}}$} \\
\hline & B & $\mathrm{Cl}$ & B & $\mathrm{Cl}$ & $\bar{B}$ & $\mathrm{Cl}$ \\
\hline Constant & - & - & $25.00^{* * *}$ & $25.60-60.60$ & $24.06^{* * *}$ & $23.60-57.97$ \\
\hline Testing rate & $0.04^{* * *}$ & $0.02-0.07$ & $0.08^{* * *}$ & $0.05-0.11$ & $0.08^{* * *}$ & $0.05-0.10$ \\
\hline Test positivity rate & $4.04^{* * *}$ & $2.20-5.91$ & $4.32^{* * *}$ & $2.6-6.08$ & $4.29^{* * *}$ & $2.73-5.87$ \\
\hline Bacteriologically diagnosed & $-1.84^{* * *}$ & $-2.58--1.10$ & $-1.43^{* * *}$ & $-2.06--0.8$ & $-1.45^{* * *}$ & $-2.02--0.88$ \\
\hline Treatment success rate & 0.99 & $0.97-1.02$ & 0.06 & $-1.45-1.59$ & 0.07 & $-1.34-1.5$ \\
\hline Vaccination coverage & $1.88^{* * *}$ & $1.38-2.38$ & $1.15^{* * *}$ & $0.52-1.78$ & $1.17^{* * *}$ & $0.61-1.72$ \\
\hline Migrant distribution & $1.5^{* * *}$ & $1.06-1.9$ & 0.61 & $-0.63-1.86$ & 0.64 & $-0.51-1.81$ \\
\hline Facility density & -9.19 & $-20.01-3.10$ & $20.64^{* *}$ & $7.94-34.84$ & $20.41^{* * *}$ & $8.42-33.72$ \\
\hline Poverty headcount ratio & $-1.87^{* * *}$ & $-90.40--75.37$ & 6.42 & $-36.05-77.09$ & 16.56 & $-25.55-82.48$ \\
\hline Stunting & $-1.27^{*}$ & $-2.47--0.05$ & 1.55 & $-1.18-4.37$ & 1.52 & $-0.94-4.04$ \\
\hline Under-five mortality rate & $-1.86^{* *}$ & $-2.15--0.47$ & -0.55 & $-2.19-1.1$ & -0.55 & $-2.06-0.99$ \\
\hline Security & -0.11 & $-0.43--0.21$ & -7.35 & $-45.33-56.99$ & -7.85 & $-42.66-48.11$ \\
\hline Global Moran's I of the residuals & & & 0.11 & & -0.04 & \\
\hline P-value of global Moran's I & & & 0.01 & & 0.14 & \\
\hline
\end{tabular}

${ }^{a}$ Generalized linear multivariable model for the natural logarithm of the TB case notification rate; not adjusted for spatial autocorrelation

${ }^{\mathrm{b}}$ Simultaneous autoregressive multivariable model for the natural logarithm of the TB case notification rate; adjusted for spatial autocorrelation All coefficients (B) are exponentiated and reflect percentage change in TB case notification rate

${ }^{*} p<0.05,{ }^{* *} p<0.01,{ }^{* * *} p<0.001$

remains that data from different years does not accurately reflect the situation in the year from which TB data were available. Furthermore, some data were only available on a higher administrative level (e.g. province or regional). These data could not be used to reflect the district-level variations that this study is trying to address. In addition, these data points are not independent from one another, which increases the risk of a type II error. Finally, subnational data on HIV or TB prevalence were not available for this study and could therefore not be included.

\section{Conclusion}

The results give clear indications of spatial clustering of the tuberculosis case notification rates in Bangladesh, Nepal and Pakistan. Where this is a result that is often found by other research concerning spatial epidemiology of TB, most of these studies attribute this to social and demographic indicators and neglect the influence that TB program efforts might have.

The result of this study show that notification of TB is mainly associated with access to healthcare and TB program efforts. This is not necessarily a problem in case the local efforts are a direct response to the TB burden, in which TB notification rates can be used as a proxy for TB incidence. However, the associations that were found do not suggest that the TB program efforts are a response to TB burden. In fact, they suggest that TB notification is dependent on programmatic response such as the ability to test, diagnose and treat individuals, but also the ability of patients to access health care. Hence, TB notifications should not be used as a proxy for $\mathrm{TB}$ incidence.

However, TB notifications are a great source of information if they are interpreted in the context of the local health system. As such, assessing changes over time in the geographical distribution of TB notification rates can be useful to monitor changes in policy, interventions or programmatic efforts. Spatial analytical techniques and profiling allows for the identification of spatial outliers and local inconsistencies which can be indicative of TB under notification. This valuable information can be used to prioritize areas which require further supervision and tailor interventions according to their local needs in an effort to diagnose and successfully treat the missing people with TB.

\section{Supplementary information}

Supplementary information accompanies this paper at https://doi.org/10. 1186/s12879-020-05207-z.

Additional file 1. Correlation Matrices of Bangladesh, Nepal and Pakistan. Three individual correlation matrices for Bangladesh, Nepal and Pakistan.

\section{Abbreviations}

Cl: Confidence interval; CNR: Case notification rate; DHS: Demographic and Health Survey; Gi: Global Moran's I; GIS: Geographical Information System; GLM: Generalized Linear Model; HIV: Human Immunodeficiency Virus; LISA: Local Indicators of Spatial Autocorrelation; MICS: Multiple Indicator 
Cluster Survey; NTP: National TB Program; SAR: Simultaneous Autoregressive model; SES: Socio economic status; TB: Tuberculosis

\section{Acknowledgements \\ Not applicable.}

\section{Authors' contributions}

MG analysed the data. RF, PJ, SCV and AHK participated in interpretation and contextualization of the results. ER, MIB, LB and CM conceived of the study and participated in its design and coordination. All authors have read an approved the final manuscript.

\section{Funding}

No funding was obtained for this study

\section{Availability of data and materials}

Part of the data used for this study comes from publicly available documents such as the Demographic and Health Survey or reports from National Statistical Offices. All publicly available documents used for this study can be found in the references of this article.

All TB data that support the finding of this study are available from the National TB programs from which they were retrieved but restrictions apply to the availability of these data, which were used under license for the current study, and so are not publicly available. Data are however available from the authors upon reasonable request and with permission of the National TB programs.

\section{Ethics approval and consent to participate}

Not applicable.

\section{Consent for publication}

Not applicable.

\section{Competing interests}

No competing interest to declare.

\section{Author details}

${ }^{1}$ KIT Royal Tropical Instituter, Amsterdam, Netherlands. ${ }^{2}$ National TB Control Program, Islamabad, Pakistan. ${ }^{3}$ National Tuberculosis Programme, Kathmandu, Nepal. ${ }^{4}$ National Tuberculosis Control Program, Dhaka, Bangladesh.

Received: 15 November 2019 Accepted: 29 June 2020

Published online: 10 July 2020

\section{References}

1. Stop TB Partnership. The paradigm shift 2016-2020: Global Plan to End TB [Internet]. Geneva: Stop TB Partnership; 2015 [cited 2018 Jan 10]. Available from: http://www.stoptb.org/assets/documents/global/plan/ GlobalPlanToEndTB_TheParadigmShift_2016-2020_StopTBPartnership.pdf.

2. World Health Organization. Global tuberculosis report 20182018.

3. Knechel NA. Tuberculosis: pathophysiology, clinical features, and diagnosis. Crit Care Nurse. 2009 Apr 1;29(2):34-43.

4. Uplekar M, Creswell J, Ottmani S-E, Weil D, Sahu S, Lönnroth K. Programmatic approaches to screening for active tuberculosis. Int J Tuberc Lung Dis Off J Int Union Tuberc Lung Dis. 2013 Oct;17(10):1248-56.

5. Hadley M, Maher D. Community involvement in tuberculosis control: lessons from other health care programmes. Int J Tuberc Lung Dis. 2000; 4(5):401-8.

6. Somma D, Thomas BE, Karim F, Kemp J, Aria N, Auer C, et al. Gender and socio-cultural determinants of TB-related stigma in Bangladesh, India, Malawi and Colombia [special section on gender and TB]. Int J Tuberc Lung Dis. 2008;12(7):856-66

7. Abebe G, Deribew A, Apers L, Woldemichael K, Shiffa J, Tesfaye M, et al. Knowledge, health seeking behavior and perceived stigma towards tuberculosis among tuberculosis suspects in a rural community in Southwest Ethiopia. PLoS One. 2010;5(10):e13339.

8. Needham DM, Bowman D, Foster SD, Godfrey-Faussett P. Patient care seeking barriers and tuberculosis programme reform: a qualitative study. Health Policy. 2004;67(1):93-106.
9. Floyd K, Blanc L, Raviglione M, Lee J-W. Resources required for global tuberculosis control. Science. 2002;295(5562):2040-1.

10. Joseph HA, Shrestha-Kuwahara R, Lowry D, Lambert LA, Panlilio AL, Raucher BG, et al. Factors influencing health care workers' adherence to work site tuberculosis screening and treatment policies. Am J Infect Control. 2004; 32(8):456-61.

11. de Vries SG, Cremers AL, Heuvelings CC, Greve PF, Visser BJ, Bélard S, et al. Barriers and facilitators to the uptake of tuberculosis diagnostic and treatment services by hard-to-reach populations in countries of low and medium tuberculosis incidence: a systematic review of qualitative literature. Lancet Infect Dis [Internet]. [cited 2017 Apr 4]; Available from: http://www. sciencedirect.com/science/article/pii/S147330991630531X.

12. Nanoo A, Izu A, Ismail NA, Ihekweazu C, Abubakar I, Mametja D, et al. Nationwide and regional incidence of microbiologically confirmed pulmonary tuberculosis in South Africa, 2004-12: a time series analysis. Lancet Infect Dis. 2015;15(9):1066-76.

13. Tiwari N, Adhikari CMS, Tewari A, Kandpal V. Investigation of geo-spatial hotspots for the occurrence of tuberculosis in Almora district, India, using GIS and spatial scan statistic. Int J Health Geogr. 2006;5(1):33.

14. Kakchapati S, Yotthanoo S, Choonpradup C. Modeling tuberculosis incidence in Nepal. Asian Biomed. 2010;4:2.

15. Wang T, Xue F, Chen Y, Ma Y, Liu Y. The spatial epidemiology of tuberculosis in Linyi City, China, 2005-2010. BMC Public Health. 2012;12(1):885.

16. Couceiro L, Santana P, Nunes C. Pulmonary tuberculosis and risk factors in Portugal: a spatial analysis. Int J Tuberc Lung Dis. 2011;15(11):1445-55.

17. Maciel ELN, Pan W, Dietze R, Peres RL, Vinhas SA, Ribeiro FK, et al. Spatial patterns of pulmonary tuberculosis incidence and their relationship to socioeconomic status in Vitoria, Brazil. Int J Tuberc Lung Dis. 2010;14(11):1395-402.

18. Theron G, Jenkins HE, Cobelens F, Abubakar I, Khan AJ, Cohen T, et al. Data for action: collection and use of local data to end tuberculosis. Lancet. 2015; 386(10010):2324-33.

19. NIPORT/Bangladesh NI of PR and T-, Associates M and, International ICF. Bangladesh Demographic and Health Survey 2014. 2016 [cited 2018 Jan 11]; Available from: http://dhsprogram.com/publications/publication-fr311-dhsfinal-reports.cfm.

20. Bangladesh EPI Coverage Evaluation Survey 2015. Mohakhali, Bangladesh: Center for Social and Market Research; 2016.

21. Department of Health Services. Annual Report 2013/2014. Kathmandu: Ministry of Health and Population; 2015.

22. Elderly Population in bangladesh: Current Features and Guture Perspectives, Dhaka, Bangladesh: Bangladesh Bureau of Statistics; 2015. (Population Monograph). Report No.: 42015.

23. FATA Development Indicators household survey 2013-14 [internet]. Peshawar, Pakistan: Bureau of Statistics; 2015 [cited 2017 Jul 20]. Available from: https://unstats.un.org/unsD/demographic/sources/census/wphc/ Nepal/Nepal-Census-2011-Vol1.pdf.

24. Naveed A, Wood G, Ghaus MU. Geography of Poverty in Pakistan- 2008-09 to 2012-13: Distribution, Trends and Explanations. Think Asia [Internet]. 2016 Jun 30 [cited 2018 Jan 11]; Available from: https://think-asia.org/ handle/11540/7074.

25. Literacy Trends in Pakistan. Islamabad, Pakistan: UNESCO Office;

26. Nepal Demographic and Health Survey 2011 [Internet]. Kathmandu, Nepal: Ministry of Health and Population, New ERA, and ICF International, Calverton, Maryland: Ministry of Health and Population (MOHP) [Nepal], New ERA, and ICF International Inc; 2012 [cited 2017 Jul 20]. Available from: http://dhsprogram.com/pubs/pdf/fr257/fr257\%5B13april2012\%5D.pdf.

27. Sharma P, Guha-Khasnobis B, Khanal DR. Nepal Human Development Report 2014. Kathmandu: Government of Nepal National Planning Commission; 2014.

28. Nepal Living Standards Survey 2010/2011 [Internet]. Kathmandu, Nepal: Central bureau of Statistics; 2011 [cited 2017 Jul 20]. Available from: http:// siteresources.worldbank.org/INTLSMS/Resources/3358986-1181743055198/3 877319-1329489437402/Statistical_Report_Vol1.pdf.

29. Rahman MN, Kamal GM, Rahman MM, Sultana S, Abdullah HP, Parvin A Mondal SR, Alam MD. Population and Housing Census 2011 - SocioEconomic and Demographic Report. Dhaka: Bangladesh Bureau of Statistics; 2012. (National Series). Report No.: 4.

30. Progotir Pathey Multiple Indicator Cluster Survey 2012-2013, Key Findings [Internet]. Dhaka, Bangladesh: Bangladesh Bureau of Statistics and UNICEF Bangladesh; 2014 [cited 2017 Jul 20]. Available from: https://www.unicef. org/bangladesh/MICS_Key_Findings_Report_revised_05-08-2015.pdf. 
31. Social Demography. Katmandu, Nepal: Central Bureau of Statistics; 2014. (Population Monograph of Nepal). Report No.: 2.

32. Bangladesh Bureau of Statistics-Government of the People's Republic of Bangladesh | বাংলাদশে পরসিংখৃযান ব্যুর্ন-গণপ্রজাতন্ত্রী বাংলাদশে সরকার [Internet]. [cited 2018 Jan 10]. Available from: http://www.bbs.gov.bd/.

33. Central Bureau of Statistics [Internet]. [cited 2018 Jan 10]. Available from: http://www.cbs.gov.np/.

34. Pakistan Bureau of Statistics [Internet]. [cited 2018 Jan 10]. Available from: http://www.pbs.gov.pk/.

35. The DHS Program - Quality information to plan, monitor and improve population, health, and nutrition programs [Internet]. [cited 2018 Jan 10]. Available from: https://dhsprogram.com/.

36. Global Administrative Areas | Boundaries without limits [Internet]. [cited 2018 Jan 10]. Available from: http://gadm.org/.

37. DIVA-GIS | free, simple \& effective [Internet]. [cited 2018 Jan 10]. Available from: http://www.diva-gis.org/.

38. Team G. GeoNetwork opensource portal to spatial data and information [Internet]. 2007 [cited 2018 Jan 11]. Available from: http://www.fao.org/ geonetwork/srv/en/metadata.show?id=12691.

39. Organization WH. Definitions and reporting framework for tuberculosis2013 revision. 2013:

40. Levesque J-F, Harris MF, Russell G. Patient-centred access to health care: conceptualising access at the interface of health systems and populations. Int J Equity Health. 2013 Mar 11;12:18.

41. Dangisso MH, Datiko DG, Lindtjørn B. Accessibility to tuberculosis control services and tuberculosis programme performance in southern Ethiopia. Glob Health Action. 2015;8 Available from: http://www.ncbi.nlm.nih.gov/ pmc/articles/PMC4655224/.

42. Datar A, Mukherji A, Sood N. Health infrastructure \& immunization coverage in rural India. Indian J Med Res. 2007;125(1):31-42.

43. Lönnroth K, Jaramillo E, Williams BG, Dye C, Raviglione M. Drivers of tuberculosis epidemics: the role of risk factors and social determinants. Soc Sci Med. 2009 Jun 1;68(12):2240-6.

44. Horton KC, MacPherson P, Houben RMGJ, White RG, Corbett EL. Sex differences in tuberculosis burden and notifications in low- and middleincome countries: a systematic review and meta-analysis. PLoS Med. 2016 Sep 6;13(9):e1002119.

45. WHO | Moderate malnutrition [Internet]. WHO. [cited 2017 Jun 16]. Available from: http://www.who.int/nutrition/topics/moderate_malnutrition/en/.

46. Dhavan P, Dias HM, Creswell J, Weil D. An overview of tuberculosis and migration. Int J Tuberc Lung Dis Off J Int Union Tuberc Lung Dis. 2017;21(6): 610-23.

47. Ross MH. Occupational respiratory disease in mining. Occup Med. 2004 Aug 1;54(5):304-10.

48. World Development Indicators 2007. World Bank Publications; 2007. 430 p.

49. McCarthy KD, Metchock B, Kanphukiew A, Monkongdee $P$,

Sinthuwattanawibool C, Tasaneeyapan T, et al. Monitoring the performance of mycobacteriology laboratories: a proposal for standardized indicators. Int J Tuberc Lung Dis. 2008 Sep 1;12(9):1015-20.

50. Twisk JWR. Inleiding in de toegepaste biostatistiek; 2014.

51. Limpert E, Stahel WA, Abbt M. Log-normal distributions across the sciences: keys and clues: on the charms of statistics, and how mechanical models resembling gambling machines offer a link to a handy way to characterize log-normal distributions, which can provide deeper insight into variability and probability—normal or log-normal: that is the question. AIBS Bull. 2001; 51(5):341-52.

52. QGIS D. QGIS geographic information system. Open source geospatial Foundation project. 2015

53. Team Rs. RStudio: integrated development for R. Boston MA URL Httpwww Rstudio Com: RStudio Inc; 2015.

54. Anselin L, Syabri I, Kho Y. GeoDa: an introduction to spatial data analysis. Geogr Anal. 2006;38(1):5-22.

55. Onozaki I, Law I, Sismanidis C, Zignol M, Glaziou P, Floyd K. National tuberculosis prevalence surveys in Asia, 1990-2012: an overview of results and lessons learned. Tropical Med Int Health. 2015 Sep;20(9):1128-45.

56. Myers WP, Westenhouse JL, Flood J, Riley LW. An ecological study of tuberculosis transmission in California. Am J Public Health. 2006 Apr;96(4): 685-90.

57. Irfan SD, Faruque MO, Islam MU, Sanjoy SS, Afrin D, Hossain A. Sociodemographic determinants of adult tuberculosis: a matched case-control study in Bangladesh. Am J Infect Dis. 2017 Mar 1;13(3):32-7.
58. Karim M, Rahman M, Mamun S, Alam M, Akhter S. Risk factors of childhood tuberculosis: a case control study from rural Bangladesh. WHO South-East Asia J Public Health. 2012;1(1):76.

59. NATIONAL TB PREVALENCE SURVEY (2018-19) - FACTSHEET. National Tuberculosis Control Centre;

60. Creswell J, Rai B, Wali R, Sudrungrot S, Adhikari LM, Pant R, et al. Introducing new tuberculosis diagnostics: the impact of $\mathrm{Xpert}^{\oplus} \mathrm{MTB} / \mathrm{RIF}$ testing on case notifications in Nepal [Internet]. 2015 [cited 2020 Apr 3]. Available from: https://www.ingentaconnect.com/content/iuatld/ijtld/2015/00000019/ 00000005/art00010.

61. Lakew Y, Bekele A, Biadgilign S. Factors influencing full immunization coverage among 12-23 months of age children in Ethiopia: evidence from the national demographic and health survey in 2011. BMC Public Health. 2015 Jul 30;15(1):728.

\section{Publisher's Note}

Springer Nature remains neutral with regard to jurisdictional claims in published maps and institutional affiliations.
Ready to submit your research? Choose BMC and benefit from:

- fast, convenient online submission

- thorough peer review by experienced researchers in your field

- rapid publication on acceptance

- support for research data, including large and complex data types

- gold Open Access which fosters wider collaboration and increased citations

- maximum visibility for your research: over $100 \mathrm{M}$ website views per year

At BMC, research is always in progress.

Learn more biomedcentral.com/submissions 